\title{
The Effect of Chloride Acid Concentration and Demineralization Time on Gelatin Characteristic of EEL Fish Bones (Anguilla marmorata (Q.) Gaimard)
}

\author{
Jamaluddin*, Angriani Abdullah and Yonelian Yuyun \\ Department of Pharmacy, Mathematics and Natural Science of Faculty, Tadulako University, Palu City, \\ Central Sulawesi, Indonesia
}

\begin{abstract}
Anguilla marmorata (Q.) Gaimard, eel bonefish is one of the potentials sources for gelatin manufacture. This study aims to determine the concentration of hydrochloric acid ( $3 \% ; 4 \%)$ and to optimize demineralization time (12 hours; 24 hours) for thequality of gelatin. Characteristic of gelatin was determined by analysis of water content, ash content and protein content. To optimize gelatin extraction from eel fish bone, Mann Whitney test with 4 - factor was adopted. Spectrophotometer FTIR was used to analyze functional groups of gelatin. Values of water content, ash and protein content of each combination of acid chloride and demineralization time have met the requirements. The spectrum of FTIR showed a typical gelatin functional group. The best combination of treatment is at $3 \%$ hydrochloric acid concentration and 12 hours of demineralization time.
\end{abstract}

Keyword: Gelatin, Anguilla marmorata (Q.) Gaimard, fish bone, demineralization.

\section{INTRODUCTION}

In Indonesia, the need for gelatin is increasing and it can be seen from the imported amount in 2002 of 2,144 tons, in 2003 amounted to 6233 tons. Statistically, the imports done by Indonesian government in the period of January-December 2009 was amounted to $3,124,255 \mathrm{~kg}$ with a value of $16,741,918$ US \$. Gelatin supplier countries to Indonesia are China, Japan, France, Australia, India, and New Zealand [1].

Gelatin is widely used in the pharmaceutical, food and non-food industry. In food industry, gelatin used for gelling, thickening, emulsifying, and foaming. While in pharmaceutical company, gelatin is commonly used as ingredient of soft and hard capsules for medicines and food supplements, forming and wrapping material of tablets and pills, and mixture ingredient in lotions, creams, and cosmetics [2].

Karim and Bhat (2009) [3] reported that the annual global gelatin production is 326,000 tons; where the gelatin from pig skin constitute $46 \%$, cow leather $29.4 \%$, cow bones $23.1 \%$ and other sources $1.5 \%$. The factor restricting free consumption of products containing gelatin is religious. For example the Hindus are forbidden to eat beef; Muslims and Jews are forbidden to consume any products derived from pigs.

*Address correspondence to this author at the Department of Pharmacy, Mathematics and Natural Science of Faculty, Tadulako University, Palu City, Central Sulawesi, Postal: 94118, Indonesia; Tel: +6281355198799;

E-mail: jamal_farmasi02@yahoo.co.id
This condition calls for alternative sources of gelatin. One potential source of gelatin is fish skin and bones.

Central Sulawesi has several endemic species of fish scattered in Poso Lake. In general, the type of fish in the Poso Lake include: Cork fish (Channa striata), Betook fish (Anabas testudineus), Nilem fish (Osteochillus hasseltii), Sogili fish (Anguilla marmorata), Nila fish (Oreochromis niloticus), Anasa fish (Nomorhampus celebensis), Tempel Batu fish (Tamanka sarasinorum) and Rono fish (Oryzias nigrimas) [4].

Rizky, et al. (2013) [5] founded that gelatin on Tenggiri fish bone for moisture content of $7.9568 \%$, ash content $1.9444 \%$, total $\mathrm{N}$ content $4,3356 \%$ and protein content $27.097 \%$ has fulfilled SNI gelatin. Indonesian National Standard (SNI) number 06-3735 in 1995 for gelatin is $3.25 \%$ of ash content, $16 \%$ of moisture content,and $79.40 \%$ of protein content.

Based on that, it is necessary to do research on the quality of bone gelatin in Central Sulawesi endemic fish species, eel Anguilla marmorata (Q.) Gaimard collected from Poso Lake. The best of our knowledge, there is not found publications regarding this matter.

\section{MATERIALS AND METHODS}

\section{Materials}

The material used in this study is eel boneobtained from Poso Lake. Other ingredients used were 10\% formalin, $3 \%$ solution of hydrochloric acid $(\mathrm{HCl})$ and $4 \%$

() 2019 SET Publisher 
sulfuric acid $\left(\mathrm{H}_{2} \mathrm{SO}_{4}\right), 30 \%$ sodium hydroxide $(\mathrm{NaOH})$, distilled water, methylred indicator, potassium bromide $(\mathrm{KBr})$, and $2 \%$ boric acid $\left(\mathrm{H}_{3} \mathrm{BO}_{3}\right)$.

\section{Methods}

\section{Sample Preparation}

Fish sample was washed using flowing water to clear the mucus. Then the internal organs (viscera and gills) were excluded and washed again. The cleaned fish was sliced by knife to separate the bones from the flesh. Then the fish bones were washed and subjected for futher analysis.

\section{Preparation of Gelatin}

\section{Degreasing}

About $2 \mathrm{~kg}$ of fish bones that have been cleaned was immersed in boiling water for \pm 30 minutes by stirring, then cut into small pieces of size $1-1.5 \mathrm{~cm}$ and then drained and dried under sunlight $[6,7]$.

\section{Demineralization}

The bones that have been degreased (50 grams) was soaked in a $250 \mathrm{ml}$ solution of hydrochloric acid $(\mathrm{HCl}) 3 \%$ and $4 \%$ with the combination of soaking duration of 12 and 24 hour until forming Ossein (soft bone), hen it was filtered and washed with water until the $\mathrm{pH}$ of washing water becomes neutral [6].

\section{Extraction}

The neutralized Ossein (soft bone) was mixed with distilled water (ratio 3:1) and heat on water bath at $70^{\circ} \mathrm{C}$ for 5 hours. After that, it was filtered by the filter cloth to separate the filtrate and residue. The filtrate was taken and subjected to drying stage [6]

\section{Drying}

The samples were extracted dried in an oven at a temperature of $55^{\circ} \mathrm{C}$ for \pm 24 hours. After drying then it carried downsizing and the sample was ready for analysis [6].

\section{Determining the Quality Gelatin [3]}

\section{Yield}

The yield was obtained by comparing the weight of dried gelatin from gelatin extraction with weight of fresh material using the formula:

$$
\operatorname{Yield}(\%)=\frac{\text { dried gelatin weight }(g)}{\text { bones net weight }} \times 100 \%
$$

\section{Water Content}

Firstly, empty cup was put in an oven for 1 hour at a temperature of $105^{\circ} \mathrm{C}$, then let it cool in desiccators for 15 minutes and weighed. 1 gram sample was added into the cup, then dried in oven at $100-105^{\circ} \mathrm{C}$ for 3 hours. The cup was cooled in a desiccators for 15 minutes and weighed again. The procedure was repeated until obtained constant weight. Water content was calculates as:

Water Content $(\%)=\frac{B-A}{\text { Sample Weight }} \times 100 \%$

Where:

$A=$ weight (sample + cup) after drying $(g)$

$\mathrm{B}=$ weight (sample + cup) before drying $(\mathrm{g})$

\section{Ash Content}

Porcelain cup was heated in an oven for 1 hour at $105^{\circ} \mathrm{C}$ and then cooled in a desiccators for 15 minutes and weighed. A sample of $1 \mathrm{~g}$ was added into the dried cup and put in furnace. Porcelain then was burned until being ash at temperature of $600^{\circ} \mathrm{C}$. After that, it was cooled in desiccators for 30 minutes and weighed. The procedure was repeated until reached constant weight. The ash content was calculated as:

$$
\text { ash Content }(\%)=\frac{\text { ash weight }(g)}{\text { sample weight }(g)} \times 100 \%
$$

\section{Protein Content}

Determination of protein analysis was done by micro-Kjeldahl method [8]. The sample was weighed $0.5 \mathrm{~g}$ and put in a $100 \mathrm{ml}$ Kjeldahl flask. Then added $1.2 \mathrm{~g}$ of catalyst mixture and $10 \mathrm{ml}$ of concentrated $\mathrm{H}_{2} \mathrm{SO}_{4}$. Samples were destructed until solution become clear and then cooled. After that, $50 \mathrm{ml}$ of distilled water and $5 \mathrm{ml} 30 \% \mathrm{NaOH}$ were added and then it was distillated. Distillate was patched in $250 \mathrm{ml}$ Erlenmeyer flask containing a mixture of $15 \mathrm{ml}$ of $2 \%$ boric acid $\left(\mathrm{H}_{3} \mathrm{BO}_{3}\right)$ and 4 drops of methyl red indicator. Once the volume of distillate reached $40 \mathrm{ml}$ and color turn into bluish-green, the distillation process was stopped. The distillate was titrated with $0.01 \mathrm{~N} \mathrm{HCl}$ until end point of titration signed by the changes of pink color. The titrant volume is read and noted. The blank solution was analyzed as the sample procedure. Protein content was calculated as:

$\% N=\frac{(m l H C l-\text { mlblanko }) N H C l \times 14.007 \times f p \times 100100 \%}{m g \text { sample }}$ 
Table 1: The Water, Ash, and Protein Content of the Gelatin

\begin{tabular}{|c|c|c|c|c|c|}
\hline \multirow{2}{*}{ Parameter } & \multicolumn{4}{|c|}{ Test results } & $\begin{array}{c}\text { Indonesian national standard } \\
\text { 06-3735 (1995) }\end{array}$ \\
\cline { 2 - 6 } & $\mathbf{A}_{1} \mathbf{B}_{1}$ & $\mathbf{A}_{2} \mathbf{B}_{1}$ & $\mathbf{A}_{1} \mathbf{B}_{2}$ & $\mathbf{A}_{2} \mathbf{B}_{2}$ & Max $16 \%$ \\
\hline \hline Water Content & $9.80 \%$ & $11.10 \%$ & $9.55 \%$ & $9.23 \%$ & Max $3.25 \%$ \\
\hline Ash Content & $0.76 \%$ & $0.90 \%$ & $5.61 \%$ & $9.28 \%$ & Max $79.40 \%$ \\
\hline Protein Content & $66.71 \%$ & $65.80 \%$ & $66.65 \%$ & $64.53 \%$ & \\
\hline
\end{tabular}

Note: $A_{1} B_{1}(12$ hours $3 \%), A_{2} B_{1}(24$ hours $3 \%), A_{1} B_{2}(12$ hours $4 \%), A_{2} B_{2}$ (24 hours $\left.4 \%\right)$.

\% Protein: $\% \mathrm{~N} \times 6.25$

Where:

$14.007=$ atomic weight of Nitrogen,

$6.25=$ nitrogen protein conversion factor

\section{Characterization of Gelatin Functional Groups}

Gelatin Functional groups were determined by Fourier Transform Infra Red (FTIR) spectroscopy using potassium bromide $(\mathrm{KBr})$ pellet method. $2 \mathrm{mg}$ powders of gelatin were mixed with $100 \mathrm{mg}$ of dried $\mathrm{KBr}$ and pounded until being smooth. The mixture was then compressed into a mold using a hydraulic pump to form a thin chip (pellet) $[6,7]$.

\section{Data Analysis}

The experimental design is completely randomized design using four levels of treatment concentration of hydrochloric acid and the best demineralization time: 12 hours 3\%, 24 hours 3\%, 12 hours 4\%, and 24 hours $4 \%$. Data analysis was performed by Analysis of variants (ANOVA) one-way as a comparison test average value using SPSS (Statistical Product and Service Solution) and continued with Mann-Whitney test to determine the best time and concentration.

\section{RESULTS}

Results of analysis of water content, ash content, and protein content of Anguilla marmorata eel fish bone at varied time and concentration can be seen in Table 1. It is clearly shown that all samples fulfilled the requirement of Indonesian national standard, except for $A_{1} B_{2}\left(12\right.$ hours $4 \%$ ) and $A_{2} B_{2}(24$ hours $4 \%$ ) did not qualify for the ash content.

The Fourier Transform Infrared (FTIR) Spectrophotometer of the gelatin is presented in Figure 1.

Spectrum of IR gelatin: (a) Anguilla marmorata 12 hours 3\%, (b) Anguilla marmorata 24 hours 3\%, (c)
Anguilla marmorata 12 hours 4\%, (d) Anguilla marmorata 24 hours $4 \%$.

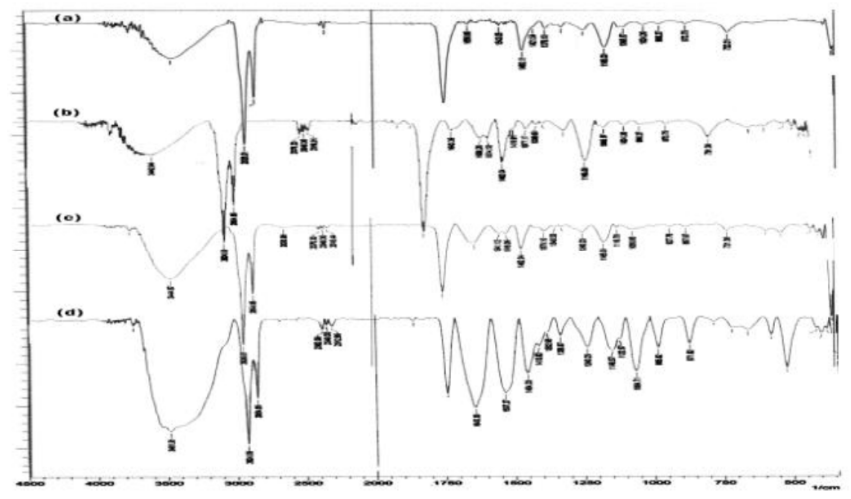

Figure 1: Result Analysis of FTIR (FourierTransform Infrared) of gelatin.

Result of One way Anova Analisys About effect of the Concentration and Demineralization Time on gelatin characteristic (Moisture, Ash and Protein Content) of eel fish bones Anguilla marmorata (Q.) Gaimard describe in Table 2.

\section{DISCUSSION}

This study was conducted to analyze and determine the quality of gelatin of the bones eel Anguilla marmorata (Q.) Gaimard was newly taken from Poso Lake. Gelatin is a protein derived from the partial hydrolysis of collagen from the skin, white connective tissue and bones of animals (8). Bone is composed of cells, fibers, and fillers. The filler on the bone are proteins and mineral salts. Bone contains approximately $50 \%$ water and $15 \%$ red and yellow marrow ref. Marrow consists of $96 \%$ of fat. Bones has taken the fat consists of organic materials and inorganic salts. Organic compounds in bone are consisting of proteins and polysaccharides, whereas bone inorganic compounds consisting of phosphate salts and carbonates [9].

Degreasing is a process that aims to eliminate meat, dirt, and grease on the bone eel Anguilla 
Table 2: One way Anova Analisys About Moisture, Ash, and Protein Content of Gelatin Eel Fish Bones Anguilla marmorata (Q.) Gaimard

\begin{tabular}{|c|c|c|c|c|}
\hline Time and Concentration & Replication & Moisture Content (\%) & Ash Content (\%) & Protein Content (\%) \\
\hline \multirow[t]{2}{*}{12 Hours in $3 \%$} & 1 & 9,37 & 0,79 & 67,00 \\
\hline & 2 & 10,28 & 0,74 & 66,43 \\
\hline \multicolumn{2}{|c|}{ Approximately } & 9,83 & 0,76 & 66,71 \\
\hline \multicolumn{2}{|c|}{ SD } & 0,65 & 0,03 & 0,40 \\
\hline \multirow[t]{2}{*}{24 Hours in $3 \%$} & 1 & 10,70 & 0,92 & 65,68 \\
\hline & 2 & 11,50 & 0,88 & 65,93 \\
\hline \multicolumn{2}{|c|}{ Approximately } & 11,10 & 0,90 & 65,80 \\
\hline \multicolumn{2}{|c|}{ SD } & 0,56 & 0,02 & 0,17 \\
\hline \multirow[t]{2}{*}{12 Hours in $4 \%$} & 1 & 9,12 & 6,05 & 66,56 \\
\hline & 2 & 9,99 & 5,18 & 66,75 \\
\hline \multicolumn{2}{|c|}{ Approximately } & 9,55 & 5,61 & 66,65 \\
\hline \multicolumn{2}{|c|}{ SD } & 0,61 & 0,61 & 0,13 \\
\hline \multirow[t]{2}{*}{24 Hours in $4 \%$} & 1 & 8,78 & 9,74 & 64,50 \\
\hline & 2 & 9,69 & 8,83 & 64,56 \\
\hline \multicolumn{2}{|c|}{ Approximately } & 9,23 & 9,28 & 64,53 \\
\hline \multicolumn{2}{|c|}{ SD } & 0,64 & 0,64 & 0,04 \\
\hline \multicolumn{2}{|c|}{ Significant } & 0,130 & $0,000^{*}$ & $0,002^{*}$ \\
\hline
\end{tabular}

Remarks: significant value $\mathrm{P}<0.05$, it can be concluded that there are significant differences in the moisture, ash, and protein content of the bone gelatin eel Anguilla marmorata (Q.) Gaimard.

marmorata [10]. An acid solution such as hydrochloric acid $(\mathrm{HCl})$ is able to change the collagen fibers triple helix into a single chain in a short time so that bones become soft (Ossein) [3]. The extraction process of Ossein was carried out using a water bath at $70^{\circ} \mathrm{C}$. Molecular building blocks of collagen called tropocollagen having a rod structure, in which there are three polypeptide chains of the same length, together form a structure of a helical. Water bath method was chosen because easy to use. It also can create a constant temperature and the gelatin will dissolve in warm water. In this research, the parameters of yield, moisture content, ash content, protein content, and see functional groups of gelatin with Fourier Transform Infrared (FTIR) spectroscopy were performed.

The yield is the percentage of gelatin which is calculated based on a comparison between gelatin powders produced by the weight of the raw material (fish bones) that has been cleared. Animal bone consists of collagen fibers. Bond to collagen is closed when exposed to acid, thus forming the description soluble in hot water. To obtain an extract gelatin from bone collagen hydrolysis process is required by extraction with hot water combined with acid treatment. Based on the results, the value of yield of Anguilla marmorata is $5.1 \%$. Yield calculation is performed to determine the percentage of produced gelatin, the greater the percentage of the yield obtained then showed the more effective the treatment used.

A nalysis of water content using the oven, warm gelatin samples was conducted at $100^{\circ} \mathrm{C}-105^{\circ} \mathrm{C}$ aims to evaporate water, characterized by the drying up the bone gelatin eel Anguilla marmorata. The desiccators used coolants and eliminate residual water content thus the fixed or constant weight of bone gelatin eel Anguilla marmorata is obtained. Based on the research, it is known that the water content contained in bone gelatin eel Anguilla marmorata with various concentrations of hydrochloric acid and extraction time does not affect the value of the water content of the produced gelatin. This is supported by statistical data processing of one-way ANOVA on the Table 2 which stated that the average value generated no significant difference in each treatment. Further analysis to know the best concentration of hydrochloric acid and the best demineralization time were determined by test of Mann-Whitney and it is obtained time and concentration of 12 hours $3 \%$ is $9.8 \%$. This value is not much different from the value of the water content the tenggiri fish bone is $7.95 \%$ [11]. 
The water content derived from eel bone gelatin has qualified SNI (06-3735-1995) is a maximum of $16 \%$. The high and low water content of a material is determined by nature and the material ability to attract water, and the drying process performed on the material. The water content was also one of the very important characteristics in food because the water can affect the appearance, texture, and taste of the food. High water content is resulting in ease of bacteria, molds, and yeasts to proliferate, which leads to changes in food.

A nalysis of ash content used incineration method for determining the total ash content and also to get the maximum combustion so that left only their mineral elements. Based on the results, that the ash content contained in bone gelatin eel Anguilla marmorata concentration of $3 \%$ with a soaking time of 12 hours and 24 hours obtained thevalue of $0.76 \%$ and $0.9 \%$. Values obtained are qualified SNI (06-3735-1995) while at a concentration of $4 \%$ by soaking 12 hours and 24 hours obtained value $5.61 \%$ and $9.28 \%$ the result is not qualified SNI (06-3735-1995). The maximum ash content by SNI (06-3735-1995) is $3.25 \%$. High and low ash content of a material is influenced by the demineralization process at the time of manufacture, thereby causing the ash content exceeds the ISO standard. The increasing concentration of $\mathrm{HCl}$ also increases the levels of ash resulting from the ash insoluble during the combustion process, the combustion process materials will burn to ashes so the effect on the number of minerals produced from the incineration [12]. More and more calcium is lost then the lower the ash content. Calcium is a mineral that was the most resulting cloudy yellow solution gelatin [8].

Statistical data processing of one-way ANOVA showed that there were significant differences from the average of the ash content. Determining the concentration of hydrochloric acid and demineralization of the best time to do a further test of Mann-Whitney time and concentration obtained 12 hours of $3 \%$ of $0.76 \%$ is quite good value, while the value obtained from the bone ash content of mackerel gelatin is $1.93 \%$ [11]. The lower the ash content of a material makes the higher the purity. Generally, the minerals contained in gelatin extracted from fish bones consisting of calcium, sodium, chlorine, phosphorus, magnesium, and sulfur.

$\mathrm{T}$ he kjeldhal method was used to measure the protein. Kjeldhal method is a simple method for the determination of total nitrogen in protein and nitrogen- containing compounds in food stuffs. In the analysis process has three stages: destruction, distillation, and titration. At this stage of destruction, samples were heated in concentrated sulfuric acid resulting in the decomposition of the sample into its elements, then use a catalyst mixture to fasten the process of oxidation, the sample was destructed until a clear solution. Furthermore, at this stage of distillation, ammonium sulfate is broken down into ammonia $\left(\mathrm{NH}_{3}\right)$ with the addition of $\mathrm{NaOH}$ until alkaline and heated in a distillation apparatus, distillation phase will end when the ammonia has distilled does not react with a base. Boric acid distillate container used then the amount of boric acid that reacts with ammonia can be determined by titration using hydrochloric acid $(\mathrm{HCl}) 0.01 \mathrm{~N}$ with methyl red indicator to speed up the color change so that at the end of the titration are marked with pink. The results obtained by the analysis of protein content to 12 hours of time and concentration of $3 \%(66.71 \%), 24$ hours $3 \%(65.80 \%), 12$ hours $4 \%(66.65 \%)$, and 24 hours of $4 \%(65,53 \%)$. Levels of protein derived from eel bone gelatin have qualified SNI (06-3735-1995) is a maximum of $79.40 \%$. Statistical data processing oneway ANOVA showed that there are two groups with significant different of average protein content, a group that has a high protein content based on the average is 12 hours 12 hours $3 \%$ and $4 \%$. The next test to determine the best concentration of hydrochloric acid and the best time of demineralization is test of MannWhitney which obtained 12 hours and the concentration of $3 \%$ is $66.71 \%$. This value is not much different from the value of the bone protein content of fish bones mackerel is $27.097 \%$ [11].

FTIR measurement results shown in the curve is divided into four regions, namely absorption amide $\mathrm{A}$, amide I, amide II and amide III which is typical of functional groups catchment area gelatin. in Figure 2 showed a typical FTIR analysis results in gelatin of eel Anguilla marmorata with time and concentration 12 hours of $3 \%, 24$ hours of $3 \%, 12$ hours of $4 \%$, and 24 hours of $4 \%$. Amide $A$ absorption area shown in the $3600-2300 \mathrm{~cm}$ region $^{-1}$ is an area of absorption $\mathrm{OH}$ groups, $\mathrm{NH}$ strain, and strain $\mathrm{CH}_{2}$ [13]. Thus bone gelatin eel Anguilla marmorata with time and concentration of 12 hours of $3 \%, 24$ hours of $3 \%, 12$ hours of $4 \%$, and 24 hours of $4 \%$ tested has proven to have an $\mathrm{OH}$ group, $\mathrm{NH}$ strain, and strain $\mathrm{CH}_{2}$. Regional uptake amide $\mathrm{I}$ absorption peaks are shown in the region $1661-1636 \mathrm{~cm}^{-1}$ absorption is caused by the strain of double bonds of the carbonyl group $\mathrm{C}=\mathrm{O}, \mathrm{NH}$ bonding and strain $\mathrm{CN}$. Amide I region's uptake showed the strain of $\mathrm{C}=\mathrm{O}$ and the $\mathrm{OH}$ group paired 
with a carboxyl group. The results of measurements of bone gelatin eel Anguilla marmorata with various concentrations have proven time and have a distinctive group of gelatin. Amide II absorption area is shown at 1560-1335 $\mathrm{cm}$ region. ${ }^{-1}$. Amide II vibration caused by the deformation of $\mathrm{NH}$ bonds in proteins. Amide catchment area III shown in $1240-670 \mathrm{~cm}$ region $^{-1}$ and is associated with the structure of collagen. This shows that the gelatin from the bones of eel Anguilla marmorata with time and concentration 12 hours $3 \%$, 24 hours $3 \%, 4 \%$ to 12 hours, and 24 hours of $4 \%$ are still contain collagen structure.

\section{CONCLUSION}

Time demineralization and concentration of hydrochloric acid for the best quality gelatin from the bones of eel Anguilla marmorata (Q.) Gaimard is seen from the parameters moisture, ash and protein contents, as well as the functional groups on the gelatin which is 12 hours of $3 \%$ with a yield of $5.1 \%$ and this parameters has fulfilled the requirement of SNI 063735 (1995).

\section{ACKNOWLEDGEMENT}

The authors thank Chemistry Laboratory Hasanudin University, Makassar, Indonesian for analysis of gelatin from eel fish bones Anguilla marmorata (Q.) gaimard in Poso lake.

\section{REFERENCES}

[1] Agnes TA. Gelatin fish: Source of Chemical Composition and Potential Utilization. Manado. Journal of Technology Media of Fishery Products 2013; 1(2): 44-46.

[2] Park JW, Whiteside WS, Cho SY. Mechanical and Water Vapor Barrier Properties of Extruded and Heat-Pressed Gelatin Films, LWT 2008; 41: 692-700. https://doi.org/10.1016/i.Iwt.2007.04.015
[3] Karim AA, dan Bhat R. Review Fish: Proceedings Chemistry, Mathematics and Natural Science of Faculty - Surabaya Institute of Technology; Gelatin: Properties. Challenges. And Prospects As An Alternative To Mammalia Gelatins. Trends in Food Science and Technology 2009; 19: 644-656. https://doi.org/10.1016/i.tifs.2008.08.001

[4] Sawestri S, Atminarso D. Trophic Status and Estimation of Potential Fish Production in Lake Poso waters of Central Sulawesi, Journal of Limnology Developments in Support of Sustainable Development in Indonesia. A Researcher at Research Institute of Fisheries of Public Waters, Palembang, 2013; pp. 181-191.

[5] Rizky, Fatima, Elok M. Gelatin Extraction of Macked Fish Bone Through Hydrolysis Process Using Alkaline Solution, Pharmaceutical Media, Pharmaceutical Media 2013; 10(2): 18-28.

[6] Tazwir, Diah LA, Rosmawaty P. Optimization Of Gelatin Making From Kaci-Kaci Fishbones(Plectorhynchus chaetodonoides Lac.) Using Acid Concentrations and Extraction Time, Journal of Postharvest and Marine Biotechnology and Fisheries 2007; 2(1): 35-43.

[7] Jamaluddin, Lagangka $R$, Khumaidi A. Determination of Quality and Identification of Gelatin On The Eel (Anguilla marmorata (Q.) Gaimard) fishs) Fish Skin With Varied Concentrations of Acetic Acid. International Journal of Current Research 2018; 10(8): 72670-72675.

[8] Niniet M, dan Lukman A. Analysis of Chemical, Physical, and Thermal Properties of Gelatin From Stingray Skin Extraction (Himantura gerrardi) Through Variation Types of Acidic Solutions, Proceedings Chemistry, Mathematics and Natural Science of Faculty - Surabaya Institute of Technology 2010; 1-9.

[9] Sara N. Effect of Material Type and Degreasing Time on Quality and Quantity of Chicken Bone Gelatin, Hasanuddin University, Makassar: 2014

[10] Anonim. Gelatin, http://respository.ipb.ac.id/bitstream/handle/ 123456789/46823/2012. snu_bab\%2012.\%20Tinjauan\%20 Pustaka.pdf. Accessed 27 February 2013.

[11] Indonesian National Standard (SNI) 06-3735. Quality and Method of Gelatin Test, National Standardization Board, Jakarta: 1995.

[12] Winarno FG. Food Chemistry and Nutrition. PT. Gramedia Pustaka Tama. Jakarta: 2004.

[13] Puspawati, Simpen, Sumerta M. Isolation of Gelatin from Broiler Chicken Feet and Characterization of Functional Groups With FTIR Spectrophotometry, Udayana University, Journal of Chemistry 2012; 6(1): 7987. 